\title{
KUTTAB: MADRASAH PADA MASA AWAL (UMAYYAH) PENDIDIKAN ISLAM
}

\author{
M. Mukhlis Fahruddin \\ Dosen pada program studi PGMI dan PAI UIN Malang
}

\begin{abstract}
Kuttab is fist Islamic education institute, the learning is simple system; reading, writing, physical exercise and skill. This institute development potency with Islamic character. The curriculum balanced intellectuality and spirituality. This article gives information about the firs institute education and scientific tradition in Islam. This tradition will hope motivator and innovator to development Islamic education in Indonesia. This article analyses intellectual tradition in Umayyah. The objective of the analyses awakens our awareness of intellectual tradition, because it will lead our nation into a better future. Creating such condition requires the involvement of each component of this nation
\end{abstract}

Key word: Kuttab, Madrasah, Pendidikan Islam, Anak

\section{Pendahuluan}

Bani Umayyah 41-132 H/661-750 M merupakan massa bagi umat Islam dalam meluaskan wilayah kekuasaannya. Dari rentang massa 90 tahun massa kekuasaan bagi Umayyah dan 14 khalifah Umayyah, kesemuanya adalah penakluk-penakluk daerah kekuasaan yang tangguh. Tiga khalifah terbesar bani Ummayyah, yaitu Muawiyah, Abdul Malik dan Hisyan merupakan khalifah-khalifah yang berkedudukan di Damaskus (Syria) yang menggunakan taktik pemerintahan gaya Yunani dan Persia dengan sistem monarki (Bosworth , 1992: 25).

Pada masa itu perluasan wilayah kekuasaan Islam berkembang dengan derasnya; mulai dari Afrika Utara di sebelah barat Mesir diduduki, dan pada tahun $710 \mathrm{M}$ pasukan Muslimin menyeberangi selat Giblartar lalu masuk ke Spanyol, lalu masuk ke Pyrenees dan menyerang Carolingian, Prancis. Penaklukan itu tidak berhensi di Prancis, tetapi juga merembet ke Iran, Turki dan India, sebuah negeri yang sangat jauh dari 
pusat kekuasaan Dinasti Ummayyah di Damaskus kala itu (ibid: 26) Sebuah ekspansi yang memerlulan banyak harta dan segenap pikiran. Kurun bagi Umayyah seperti yang ditulis oleh John L Esposito sebagai berikut:

Prestasi Bani Umayyah memang luar biasa. Damaskus menjadi ibukota kerajaan yang jauh lebih besar daripada ketika di bawah kekuasaan Bizantium. Para penguasa Umayyah membangun kerajaan dinasti yang terpusat kuat, sebuah imperium Arab. Pemerintahan, lembaga dan birokrasi Bizantium yang lebih maju mereka adopsi dan disesuaikan dengan kebutuhan-kebutuhan Muslim Arab (Esposito, 2004: 53).

Pada masa Umayyah memang penuh dengan peperangan dan penaklukan, sehingga membaca kurun kekuasaan Bani Umayyah, para pengkaji agama dan sejarah sering melihat kurun ini sebagai kurun ekspansi, bukan sebagai kurun pembentukan peradaban Islam yang didasarkan pada penguatan di dalam pembentukan ilmu di dalam dunia Islam. Seperti yang dikatakan oleh Charles Michael Stanton bahwa " Selama organisasi dan restrukturisasi ini pendidikan tinggi belum dikenal di dunia Islam.bani Umayyah menghabiskan waktu dan sumber daya mereka untuk membangun negara monarki sekuler (Stanton, 1994: 6)

Disisi lain, ternyata pemerintah pada waktu itu masih memperhatikan pendidikan, hal ini terbukti dengan adanya Kutab sebagai cikal bakal berdirinya lembaga-lembaga pendidikan Islam bagi masa sesudahnya. Banyak hal yang bisa kita ambil pelajaran dari tradisi keilmuan yang dikembangkan, terutama pada pendirian lembaga pendidikan Islam.

Keberadaan Kuttab telah banyak memberikan pengaruhnya dalam sejarah perkembangan pendidikan Islam, termasuk di Indonesia. Penanaman pendidikan Islam sejak dini sangatlah penting, terlebih sebagai pembekalan sejak dini untuk pembentukan kepribadian Islam.

\section{Kuttab Sebagai Lembaga Pendidikan Untuk Anak.}

Pada masa Bani Umayyah, lembaga-lembaga pendidikan berkembang dengan baik. Tapi dengan keilmuan yang masih sangat sederhana, yaitu dalam hal pengajaran Membaca dan Menulis Al-Quran, akhlak dan olah raga. Sebut saja lembaga pendidikan bernama Kuttab. 
Sebuah lembaga pendidikan untuk mengajarkan agama kepada anak-anak yang berkembang dengan baik.

Kuttab atau maktab, Mahmud Yunus menulis bahwa "Kuttab berasal dari kata dasar 'kataba' yang berarti menulis atau tempat menulis. Jadi kuttab adalah tempat belajar menulis. Sebelum datangnya Islam, kuttab telah ada di negeri Arab, walaupun belum banyak di kenal oleh masyarakat (Zuhairini,1991: 89). Tidak berbeda dengan Ahmad Syalabi yang menulis bahwa "Kuttab adalah tempat memberi pelajaran menulis," (Syalabi, 1973: 38). di mana tempat belajar membaca dan menulis ini teruntuk bagi anak-anak. Begitu juga dengan George Makdisi yang menjelaskan bahwa kuttab atau maktab merupakan institusi pembelajaran untuk anak-anak dan juga pembelajaran untuk pendidikan yang lebih tinggi lagi. Bahkan pendidikan sekelas maktab atau kuttab bisa sampai pada pembelajaran untuk spesialisasi keilmuan, seperti belajar fikh (Makdisi, 1981: 19), tapi pendapan George Makdisi tidak disepakati oleh banyak ahli sejarah pendidikan Islam, khususnya berkaitan dengan kuttab yang juga mengajarkan spesialisasi keilmuan.

Ketika perang badar terjadi dan dimenangkan oleh umat Islam, banyak tawanan dari suku Quraisy di Madinah. Nabi Muhammad waktu itu memberi alternatif kepada para tawanan dari Quraisy yang bisa membaca dan menulis, untuk memberi pelajaran membaca dan menulis kepada 10 anak dari Madinah. Bila pada tawanan ini sanggup, maka mereka akan dibebaskan.

Sejak saat itu bangkitlah minat belajar baca tulis di Madinah Perintah tulis baca ini tidak saja ditujukkan kepada anak laki-laki, tetapi juga kepada anak-anak wanita. Oleh sebab itu tidak heran, bahwa kuttab untuk belajar menulis dan membaca Al-Quran lebih berkembang pada masa Nabi Muhammad tinggal di Madinah. Bahkan di Madinah didirikan Kuttab bernama Darul Quran, tempat anak-anak belajar dan menghafal AlQuran (Yunus, 1988: 20).

Dalam sejarah juga dikemukakan bahwa di Makkah dan Madinah, kuttab sudah ada. Tetapi baru mengajarkan membaca dan menulis dan bukan mengajarkan Al-Quran:

1. Ummi Salamah, salah satu isteri Rasulullah, pernah meminta kepada seorang guru pada sebuah kuttab agar ia mengirimkan beberapa orang muridnya untuk menolongnya memberisihkan bulu dan memintalnya. 
2. Umar Ibn Maimun ada menghafal mantera untuk tangkal penyakit mata. Menurut Umar Ibnu Maimun ini mantera itu berasal dari Saad Ibnu Abi Waqqas. Saad ini pernah meliskan dan mengajarkannya mantera ini kepada putera-puteranya sebagai seorang guru mengajarkan kepada murid-muridnya.

3. Sekali peristiwa Ibnu Umar dan Asbu Usaid lalu diadakan sebuah kuttab. Murid-murid kuttab itu tertarik perhatiannya kepada Ibnu Umar dan Abu Usaid itu.

4. Batu tulis telah ada sejak jaman Islam. Ada dicerikatakan bahwa Ummu Darda' pernah menuliskan hikmat-hikmat pada batu tulis, agar dicontoh oleh murid-murid yang sedang diajarkan menulis dan membaca (Syalabi, ibid: 39).

Usia-anak-anak yang masuk kuttab adalah usia yang sudah mencapai tujuh tahun. Sebelum usia tujuh tahun, anak-anak belum diperbolehkan masuk kuttab. Hal ini seperti apa yang dikatakan oleh Abdurrahman Al-Bahgdadi, bahwa " Adalah para leluhur kita yang alim mengirimkan putra-putranya ke kuttab tatkala mereka mencapai usia tujuh tahun,"

\section{Lokasi Belajar Kuttab}

Tempat belajar anak-anak di kuttab ada di beberapa tempat. Hal ini dikarenakan kuttab pada awal pertama bukan pendidikan yang formal, sehingga tempatnya masih belum ditentukan. Tetapi ketika kuttab sudah menjadi lembaga pendidikan formal, lokasi belajar kuttab menunjukkan kesamaan:

1. Pada awalnya kuttab adalah pengajaran Al-Quran yang berlangsung di Masjid, yang sifatnya umum ( bukan hanya bagi anak-anak, tetapi juga bagi orang dewasa). Lalu anak-anak ikut pengajian di dalam, tetapi karena mereka tidak dapat diharapkan untuk menjaga kesucian dan kebersihan Masjid, lalu diadakan di tempat khusus di samping Masjid untuk tempat anak-anak belajar Al-Quran dan pokok-pokok agama.

2. Lokasi selanjutnya ada di samping masjid. Di mana anak-anak dibangunkan sebuah tempat di samping masjid. Bangunan ini terpisah dengan masjid, tetapi masih satu lokasi dengan lingkungan Masjid. Selanjutnya berhubung tempat-tempat khusus ( baik yang didalam masjid, atau terpisah) untuk pengajaran anak-anak, maka berkembanglah kuttab-kuttab yang bukan hanya mengajarkan Al- 
M. Mikihlis Fahruddin-kuttab: Madrasah pada masa awal (Umayyah)

Quran, tetapi juga pengetahuan-pengetahuan dasar lain. Dengan demikian kuttab tersebut berkembang menjadi lembaga-lembaga pendidikan yang bersifat formal (Al-Baghdadi, 1996: 79 )

3. Pengajaran kuttab juga berlangsung di rumah-rumah para guru (AlTibawi, ,1976: .213). Selain berada di Masjid, kuttab yang berada di rumah-rumah guru juga mendapat sambutan dari murid-murinya. Alasan mengapa guru-guru membuka kuttab di rumahnya, karena permintaan yang begitu deras dari orang tua murid untuk mengirimkan anaknya belajar di kuttab. Biasanya lokasi kuttab yang berada di rumah adalah di satu ruangan di dalam rumah guru, atau di luar rumah. Beberapa sumber mengatakan, bahkan para guru memanggil murid-murindnya ke lapangan sekitar Masjid atau taman umum (Stanton, ibid: 19).

Model-model pembinaan melalui pengoptimalan fungsi masjid telah dilestarikan hingga sekarang, yaitu adanya sekolah diniyah yang mengajarkan materi pendidikan Islam, TPQ yang juga mengajarkan ketrampilan membaca, menulis al-Qur'an sekaligus pengetahuan agama islam dan juga banyak para kyai yang membuka diri untuk menerima satrinya dirumah.

\section{Model Kuttab dalam Kurun Sejarah}

Sebelum membahas masalah kuttab dalam kurun yang lebih modern, dalam masa bani Umayyah terdapat dua macam kuttab. Ahmad Syalabi membagi kuttab menjadi dua berdasarkan kurun sejarahnya:

Pertama Kuttab untuk belajar menulis dan membaca. Sebelum Islam datang, kuttab model ini sudah didirikan. Diantara penduduk Makkah yang mula-mula belajar menulis huruf Arab ialah Sofyan Ibnu Umaijah Ibnu Abdu Syams dan Abu Qais Ibnu Abdi Manaf Ibnu Zuhri Ibnu Kilab. Kedua orang ini mempelajarinya dari Bisr Ibnu Abdi Malik yang mempelajarinya di negeri Hirah (Syalabi, ibid: 33).

Kuttab pada masa masa awal kekuasaan Islam adalah model kuttab yang masih tersebar tempatnya. Ada kuttab yang di masjid dan ada kuttab yang ada di rumah guru-guru. Hal ini terjadi karena derasnya permintaan siswa (yang ingin belajar) dan demi kebutuhan guru terhadap mata pencahariannya. Maka guru tersebut membuat tempat khusus di rumahnya (seperti kamar) sebagai tempat belajar (Al-Tibawi, 1979: .24).

Kuttab yang mempelajari untuk belajar menulis dan membaca adalah model kuttab yang disediakan bagi orang-orang yang ingin belajar 
menulis dan membaca. Kuttab model ini bukan model kuttab untuk belajar dan menulis Al-Quran. Mengenai bentuk pengajaran kuttab model ini, Ahmad Syalabi menulis:

Bila telah datang kecerdasan-kecerdasan pada seorang anak dikirimlah dia ke maktab. Di sana anak itu belajar menulis, berhitung dan bahasa Arab. Bila anak itu telah mahir dalam hal-hal itu, atau telah memahirkan sebahagiannya menurut tenaganya dikirimlah dia kepada seorang guru Al-Quran. Guru itu mengajarkan kepada Anak itu kitabullah, maka dihafalnya AlQuran itu siap-tiap hari seperempat hizb, separoh atau satu hizb penuh (Syalabi, ibid: 37).

Kedua Kuttab untuk belajar membaca Al-Quran dan pokok-pokok Agama lain. Dalam hal ini di masa Bani Umayyah, kutab model ini yang paling banyak diketemukan. Sebelum membahas lebih lanjut, ada kerancuan mengenai kuttab untuk belajar membaca dan menulis dengan kuttab model kedua yaitu untuk membaca Al-Quran dan pokok-pokok agama lain. Banyak orientalis yang menganggap bahwa kuttab model ini sama, padahal berbeda.

Seperti pendapat Ignaz Goldziller (dalam Ahmad Syalabi, ibid: 39) bahwa kuttab model pertama ini sama dengan kuttab model kedua. Dalam pandangan Ignaz Goldziller kedua kuttab ini sama-sama untuk belajar menulis dan membaca. Hal ini dikuatkan Goldziller dengan bukti-bukti bahwa pada masa Rasulullah di Makkah sudah ada bentuk-bentuk pengajaran membaca dan menulis.

Bagi Ahmad Syalabi, yang membedakan antara kutab yang pertama dan kuttab yang kedua adalah siapa yang belajar dan apa yang dipelajari. Kuttab model pertama jelas-jelas yang dipelajari adalah membaca dan menulis. Sedangkan yang belajar adalah orang-orang dewasa dan anakanak. Sedangkan kuttab model kedua yang dipelajari adalah membaca dan menulis Al-Quran dan pokok-pokok agama Islam. Sedangkan yang mempelajarinya adalah anak-anak.

Dalam pandangan Ahmad Syalabi, pada masa permulaan Islam, anak-anak yang belajar Al-Quran di kuttab belum banyak, bahkan tidak secara formal "hanya ada beberapa kanak kanak yang belajar dengan jalan menyelusup ke dalam lingkaran-lingkaran pelajaran orang-orang besar di 
Masjid, seperti Ali Bin Abi Thalib dan Abdullah Ibnu Abbas," tutur Ahmad Syalabi (Syalabi, Ibid:41).

\section{Kurikulum Kuttab}

Pada akhir abad pertama hijriyah, mulai timbul model kuttab, yang disamping memberikan pelajaran menulis dan membaca, juga mengajarkan Al-Quran dan pokok-pokok ajaran agama. Pada mulanya, model kuttab ini merupakan pemindahan dari pengajaran Al-Quran yang berlangsung di Masjid, yang sifatnya umum ( bukan saja sebagai anakanak, tetapi juga orang dewasa). Selanjutnya berkembang model kuttab sebagai lembaga pendidikan formal untuk anak-anak (Hasubullah, 1998:92).

Mengenai transformasi kurikulum pendidikan pendidikan di kuttab yang awal mulanya hanya membaca dan menulis, lalu menjadi pendidikan formal dengan kurikulum yang terstruktur, Ahmad Syalabi menjelaskan :

Tatkala kuttab-kuttab telah didirkan dan orang-orang yang hafal Al-Quran telah bekerja pada kuttab-kuttab itu, maka dijadikanlah Al-Quran sebagai titik pusat pelajaran rendah itu, serta ditambahi dengan beberapa pelajaran yang lain. Imam Al-Ghazali umpamanya menganjurkan supaya anak-anak mempelajari di kuttab itu Al-Quran dan cerita orang-orang saleh dan orang baikbaik, kemudian beberapa peraturan-peraturan agama, seudah itu syair, tetapi anak-anak itu haruslah dijaga dari syair tentang rindu dendam, dan asyik masyuk. Ibnu Miskawaih menambahkan pokokpokok ilmu hitung dan sedikit tata bahasa (Syalabi, ibid. 92).

Menurut dari penuturan Ahmad Syalabi di atas, fungsi kuttab pada akhirnya tidak hanya membatasi pada pemberian pelajaran membaca dan menulis Al-Quran. Pengembangan fungsi kuttab dengan memberikan beberapa mata pelajaran. Mahmud Yunus menjelaskan beberapa mata pelajaran yang diberikan di kuttab antara lain:

1. Membaca Al-Quran dan menghafalkannya.

2. Pokok-pokok agama Islam, seperti cara berwudhu, salat, puasa dan sebagainya.

3. Menulis.

4. Kisah atau riwayat orang-orang besar Islam.

5. Membaca dan menghafal syair-syair atau masar (prosa).

6. Berhitung

7. Pokok-pokok nahwu dan saraf ala kadarnya. 
Lama belajar di kuttab ini, tidaklah sama, tergantung kepada kecerdasan dan kemampuan masing-masing anak, karena sistem pengajaran pada masa itu belum dilaksanakan secara klasikal sebagaimana umumnya sistem pengajaran sekarang ini. Tetapi pada umumnya, anakanak menyelesaikan pendidikan dasar ini selama lebih 5 tahun (Yunus, ibid:50).

Sejak abad ke delapan, kuirkulum kuttab semakin disempurnakan. Kurikulum di kuttab mencakup membaca, menulis, aritmatika, dan Al-Quran sebagai teks inti. Dalam sistem ini, bahasa Arab sebagaimana Al-Quran menjadi bahasa standar umat Islam dan menjadi bentuk bahasa percakapan paling luas digunakan. Dengan semakin tersedianya Al-Quran dan puisi dalam bentuk tulisan, pelajaran tata bahasa menjadi lebih dipentingkan dalam pendidikan dasar. Al-Quran merupakan sumber ganda sebagai buku dasar-yang bernilai karena pesan religiusnya, seperti halnya sebagai pedoman dalam pembentukan kalimat pembenar (Stanton,ibid:19).

Jasa terbesar yang diberikan oleh Al-Hajjad, seorang Muaddib ( pendidikan putera-putera pembesar) adalah memperkenalkan lembaga kuttab sebagai lembaga pendidikan formal. Al-Haddad adalah guru bagi putera-putera Sulaiman Ibnu Naim yang waktu itu adalah wazir dari Ibnu Malik Bin Marwan. Walaupun dalam pandangan Syalabi bahwa Al Haddad "Belum sampai mendirikan sebuah kuttab formal," (Ahmad Syalabi, Sejarah Pendidikan Islam: 42) tetapi Al-Haddadlah yang menggunakan metode pengajaran untuk anak-anak seperti lembaga kuttab ini kepada anak-anak pembesar (Ahmad,1968: 105). selain mengajar anakanak pejabat, Al Hajdad juga mengajar anak-anak dalam starata sosial biasa, artinya anak-anak kebanyakan. Bahkan di luar lingkungan Istananya, Al Hajdad memiliki 400 santri yang belajar di kuttabnya.

Kuttab yang ada di istana juga mengalami kemajuan yang berarti kurikulum pelajarannya juga lebih disempurnakan, sesuai dengan kebutuhan anak-anak elit penguasa dan pejabat. Kelompok elit dan penguasa menekankan (keterampilan) membaca, menulis, pelajaran agama dan puisi;tetapi juga keterampilan menunggang kuda, berenang dan aritmatika. Khalifah Harun Al-Rasyid memberikan bimbingan berikut kepada guru-guru anaknya:

Aku serahkan kepadamu anakku, buah sulbiku; aku memberiku kekuasaan atasnya dan membuatnya patuh kepadamu. Karenanya kamu harus membuktikan diri sebagai orang yang layak menerima 
M. Mikihlis Fahruddin-kuttab: Madrasah pada masa awal (Umayyah)

kedudukan ini. Ajarlah dia Al-Quran, sejarah, puisi, hadis dan penghargaan terhadap kefasihan bahasa. Cegah dia dari tertawa, kecuali apda kesempatan yang sesuai. Biasalkan dia untuk menghormati pada pemuka bani Hasyim dan memberikan tempat yang sesuai kepada pemipin-pemimpin militer bila mereka menghadiri majlisnya. Jangan biarkan waktu berlalu tanpa pelajaran yang bermanfaat padanya, sebab dengan begitu ia akan menjadi masa. Mendidiklah ia dengan lemah lembut, tetapi kalau tidak cukup, engkau boleh memperlakukannya dengan keras (Stanton, ibid: 20).

Mehdi Nakostem dalam History Of Islamic Origins of Western merangkum bahwa kurikulum yang diajarkan di dalam kuttab yang sudah formal adalah "In additon ini Quran an relogions, poetry, horse manship, swimming, famous proverb, elementary aritatic, elementary grammar, manner and penmansip were thaught," (Nakostem, 1964: 46)

\section{Keberadaan Kuttab Di Indonesia.}

Transmisi keilmuan dari asal muasal Islam, yaitu Makkah dan Madinah ke Indonesia juga sejak abad ke-8 sudah terjadi. Hal ini sesuai dengan argumen bahwa misi untuk mengislamkan Nusantara adalah berasal dari orang-orang arab langsung dan bukan lewat India. Syed Naquib Al-Attas mengatakan "Teori arab" merupakan bukti yang otentik mengenai karakter Islam Nusantara yang berasal dari Arab langsung. (Dalam Azyumardi Azra, Jaringan Ulama: Timur Tengah dan Kepulauan Nusantara Abad XVII dan XVIII, (Bandung:Mizan, 1998: 28). Transmisi ini, selain berkaitan dengan masalah ajaran-ajaran Islam, juga menyangkut lembaga-lembaga pengajarannya. Salah satunya adalah lembaga kuttab yang digunakan untuk lembaga pendidikan bagi anak-anak.

Di Indonesia sekolah Islam formal yang dikenal dalam dalam sejarah Indonesia adalah sekolah Mambaul Ulum yang dibangun pada 1905 di Surakarta (Dhofier, dalam Ulumul Quran Volume yogjakarta. III No 4 Th 1992: 86). setelah itu disusun sekolah Formal khususnya Madrasah yang didirikan oleh Kiai Haji Ahmad Dahlan di Yogyakarta dan Kiai Haji Hasyim Asy'ari di pesantren Tebu Ireng. Pendirian sekolah-sekolah ini menandai eksistensi Pendidikan Islam pada masa-masa yang akan datang (Maksum,1999:107-109). 
Di samping madrasah-madasarah yang didirikan secara formal, lembaga pendidikan non formal juga masih berlangsung. Bahkan eksistensinya berupa jumlahnya melebihi madrasah formal. Lembaga pendidikan Islam ini bernama nggon ngaji. Nggon ngaji artinya tempat murid-murid belajar membaca Al-Quran. Kegiatan-kegiatan murid-murid yang mengikuti pendidikan Islam itu di sebut "Ngaji Quran", berarti belajar membaca Al-Quran (Dhofier, ibid.86).

Dalam hal ini keberadaan nggon ngaji erat hubungannya dengan keberadaan langgar atau surau. Dalam hal ini ada perbedaan antara Masjid dan langgar atau surau. Karena di langgar atau surau adalah lembaga pendidikan untuk anak-anak. Kalau untuk anak dewasa di Masjid. Di masjid pendidikan yang diakarkan adalah pelajaran kitab, sedanf di surau yang diajarkan adalah pendidikan membaca dan menulis Al-Quran (Hasbullah, ibid:133).

Di langgar atau surau ini muncul nggon ngaji yang mengajarkan membaca dan menulis Al-Quran.dengan adanya nggon ngaji ini, pendidikan untuk anak-anak di suatu desa tidak akan terabaikan. Kaberadaan nggon ngaji sangat kompatibel dengan fungsi kuttab seperti yang telah dijelaskan sebelumnya.

Umumnya nggon ngaji bersifat swadaya, sebagaimana umumnya madrasah pada masa penjajahan Belanda. Walaupun bersifat swadaya, nggon ngaji jumlahnya sangat banyak. Pada tahun 1831, pemerintah Belanda mencatatnya sebanyak 1.853 nggon ngaji dengan jumlah murid 16.556 murid, tersebar di berbagai kabupaten yang didominasi pemeluk Islam di Jawa. Pada tahun 1885,Van Den Berg menemukan 14.929 nggon ngaji dengan jumlah murid 222.663 murid (Ibid, h.88).

Mata pelajaran nggon ngaji juga tidak jauh dengan pengajaran AlQuran. biasanya anak-anak menghafal ayat-ayat pendek. Pada usia tujuh dan delapan tahun, anak-anak mulai diperkenalkan cara membaca huruf Arab sampai membaca Al-Quran. Pendidikan di nggon ngaji sebatas pada pelajaran membaca dan menulis huruf arab dan membaca Al-Quran. Sedangkan kalau ingin belajar lebih lanjut, seperti fikih, tafsir, tarikh adalah di pesantren (ibid, h.89). dalam perkembangannya ada spesialisasi nggon ngaji yang hanya mengajarkan "Membaca Al-Quran" dan "Nggon ngaji belajar bahasa Arab"

Dalam proses transmisi yang panjang, nggon ngaji yang merupakan copy-an dari lembaga pendidikan kuttab ini berubah menjadi Madrarasah Ibtidaiyah. Sebuah lembaga pendidikan formal setingkat sekolah dasar. 
Hal ini merupakan upaya pemerintah pada masa awal kemerdekaan yang perlu membuka sekolah-sekolah formal lebih banyak. Adanya nggon ngaji merupakan suatu berkah tersendiri di dalam penyelenggaraan pendidikan formal tanpa harus didirikan oleh pemerintah. Perubahan nama nggon ngaji menjadi MI ini juga merubah kurikulum pendidikannya dengan memasukkan pelajaran-pelajaran umum (Ibid, h 91).

Dalam hal ini ada persamaan antara lembaga pendidikan kuttab dengan nggon ngaji di Indonesia. Pertama, antara kuttab dan nggon ngaji merupakan lembaga pendidikan yang mengajarkan pelajaran agama Islam, baik berupa membaca dan menulis Al-Quran kepada anak-anak. Segmentasi pendidikan kepada anak-anak ini menjadikan kuttab dan nggon ngaji memiliki kesamaan dalam ha lembaga pendidikan untuk anakanak.

Kedua, Kurikulum kuttab dan nggon ngaji juga sama. Keduanya mengajarkan membaca Al-Quran dan menulis huruf arab. Kalau di Indonesia yang diutamakan adalah berlajar membaca Al-Quran dan belajar bahasa arab dasar. Selain itu adalah tambahan pelajaran serta tarikh, fikih dan lain-lain. Bageitu juga dengan anak-anak yang ingin belajar lebih lanjut, dapat belajar di pesantren.

Kuttab berupakan pendidikan Al-Quran yang efektif untuk anakanak. Di mana dengan metode yang sesuai dengan jiwa anak-anak dapat menjadikan metode pembelajaran di kuttab menjadi menyenangkan. Sisi inilah yang menjadikan kuttab menjadi model pembelajaran di dunia Islam. Dalam bentuk apapun, baik dengan TPA, nggon ngaji ataupun bentuk pengajran yang lainnya, pendidikan anak-anak di kuttab berupakan cetak biru pendidikan Al-Quran untuk anak-anak yang paling efektif dan efisien.

Dalam kurun yang panjang ini, nggon ngaji juga memberi inspirasi dalam pendirian lembaga pendidikan seperti Taman Pendidikan Al-Quran (TPA). Kuttab dan nggon ngaji yang di modernkan oleh As'ad Humam, penggangas TPA ini memang mengambil unsur-unsur kuttab dan nggon ngaji untuk TPA. Sehingga sampai hari ini lembaga pendidikan seperti Kuttab, nggon ngaji dan TPA Masih terpelihara sebagai bagian dari lembaga pendidikan Islam untuk anak-anak, walaupun dengan bentuk yang makin baru.

Lembaga-lembaga pendidikan seeprti kuttab pad amasa bani Umayyah berkembang dengan baik. Kuttab atau maktab. Kuttab berasal dari kata dasar kataba yang berarti menulis atau tempat menulis. Jadi 
kuttab adalah tempat belajar menulis. Sebelum datangnya Islam, kuttab telah ada di negeri Arab, walaupun belum banyak di kenal oleh masyarakat. Kuttab juga berarti "Tempat memberi pelajaran menulis,"

Transformasi kuttab di Indonesia dapat dilihat dari keberadaan nggon ngaji atau tempat santri-santri untuk belajar mengaji di serambi Masjid atau rumah guru. Nggon ngaji ini juga menginspirasi pendirian Madrasah formal ataupun Madrasah Diniyyah. Begitu juga dengan keberadaan lembaga pendidikan seperti Taman Pendidikan Al-Quran (TPA) yang mengambil sumber-sumbernya dari lembaga pendidikan seperti Kuttab dan nggon ngaji.

Keberadaan kuttab, nggon ngaji dan TPA sebagai lembaga pendidikan islam untuk anak-anak sampai hari ini masih terpelihara dengan baik. Pada masa mendatang tentu ada lembaga pendidikan baru yang lebih modern dari lembaga pendidikan di atas. Namun unsurunsurnya tidak akan jauh berbeda dengan lembaga pendidikan Islam untuk anak seperti kuttab.

\section{Membangun Tradisi Keilmuan Pendidikan Islam}

Jika kita perhatikan masa kejayaan Islam, tentunya hal yang menarik kita perhatikan adalah tradisi keilmuan masyarakat Islam pada waktu itu. Kesadaran akan ilmu dan kecintaan akan ilmu sangat tinggi, tradisi yang berkembang pada waktu itu adalah tradisi membaca, menulis, berdiskusi, keterbukaan/kebebasan berfikir, penelitian serta pengabdian mereka akan keilmuan yang mereka kuasai.

Tradisi itu terlihat dari; kecintaan dan penghormatan kepada Ulama' yang di sponsori oleh khalifah. para ulama biasanya open hause bagi siapa aja yang mau datang kerumahnya untuk membaca, kedudukan meraka juga dimata masyarakat sangat mulia. Sedemikian cintanya masyarakat akan ilmu sampai-sampai khalifah pada waktu itu untuk merebut hati masyarakat harus memberi perhatian kepada pengembangan ilmu. Kebebasan berpikir yang tinggi memicu tradisi berdiskusi dan berdebat, meraka menjadikan perpustakaan dan masjid sebagai tempat bertemu untuk berdiskusi. kebutuhan untuk berkarya, sehingga kemandekan pemikiran bisa diatasi.

Probem pendidikan Islam adalah problem sistemik, kita perlu melibatkan berbagai pihak untuk bisa lepas dari keterpurukan. Mulai dari pemerintah sebagai pembuat kebijakan besar bagi sistem pendidikan nasional dan sebagai pengayom pelaksanaannya, lembaga pendidikan 
Islam, pendidik, peserta didik sampai kepada orang tua pendidik (anak didik) .

Tradisi atau iklim akademis yang kondusif perlu didukung oleh berbagai pihak dari mulai kebijakan pemerintah yang mampu menyediakan fasilitas pendidikan yang memadai, fasilitas bisa berupa sarana praktikum, buku dan gedung yang kondusif untuk sarana belajar dan akses pendidikan untuk warga miskin. Pemerintah harus cermat dalam menentukan anggaran pendidikan serta mengawalnya, sehingga tidak ada penyelewengan anggaran pendidikan yang hal itu memperngaruhi pelaksanaan program pendidikan.

Bagi lembaga sekolah dan pendidik harus mampu memberikan kebijakan dalam rangka membentuk tradisi intelektul (membaca, menulis, meneliti dan berdikusi serta berkarya) di kampus atau disekolah, misalnya dengan mengadakan lomba karya tulis ilmiah, lomba penelitian, lomba debat, memberikan motivasi untuk membaca, menggunakan metode dan media yang bisa mengembangkan daya pikir, kreatifitas, membuat program-program lainya untuk pengembangan diri dan menciptakan lingkungan yang kondusif untuk belajar.

Bagi orang tua membantu menciptakan suasana akademis dirumah, dengan mengarahkan meraka untuk belajar dan selalu memotivasi meraka untuk maju. Orang tua juga berkewajiban mengawasi prilaku anak didik, orang tua juga harus mengetahui program sekolah, sehingga kegiatan sekolah terbantu oleh orang tua ketika mereka berada diluar sekolah. Antara sekolah (lembaga Pendidikan Islam), guru (pendidik) dan orang tua anak didik harus saling komunikasi; Sekolah mengetahui kebutuhan masyarakat dan masyarakat mengetahui kebutuhan sekolah, mengetahui problem anak didik dan sebagainya. Hal ini memungkinan untuk mengetahui dan selanjutnya membicarkan problem-prolem pendidikan yang sedang terjadi, sehingga ditemukan solusi yang tepat untuk berbagai pihak

Pengembangan tradisi-tradisi keintelektualan seperti diatas harus dikembangkan mulai dari pendidikan dasar. Jika tradisi tersebut tidak dikembangkan dari pendidkan dasar, maka pendidik akan kesulitan menciptakan tradisi keilmuan untuk mereka, sehingga penciptaan tradisi itu selalu terlambat untuk diterapkan.

\section{A. Penutup}


M. Mikihlis Fahruddin-kuttab: Madrasah pada masa awal (Umayyah)

Pada masa Bani Umayyah, lembaga-lembaga pendidikan berkembang dengan baik. Tapi dengan keilmuan yang masih sangat sederhana, yaitu dalam hal pengajaran Membaca dan Menulis Al-Quran, akhlak dan olah raga. Lembaga pendidikan itu bernama Kuttab. Sebuah lembaga pendidikan untuk mengajarkan agama kepada anak-anak yang berkembang dengan baik, dan menjadikan keilmuan agama sebagai filter dari tradisi yang buruk, efek negatif dari globalisasi, teknologi dan informasi. Lembaga pendidikan ini kita jadikan motivasi untuk selalu melakukan inovasi dalam pendidikan dan menjadikan pendidikan sebagai investasi sumber daya umat Islam yang nantinya akan memperbaiki kondisi zaman ke arah yang labih baik.

\section{Daftar Pustaka}

Azra Azyumardi, Jaringan Ulama: Timur Tengah dan Kepulauan Nusantara Abad XVII dan XVIII, (Bandung:Mizan, 1998) al-Baghdadi

Abdurrahman, Sistem Pendidikan Di Masa Khalifah Islam, (Surabaya: AlIzzah, 1996)

Bosworth C.E, Dinasti-Dinasti Islam, (Bandung: Mizan, 1992)

Nation System, (London:Luzac and Company,1979)

Dhofier Zamakhsyari, "Sekolah Al-Quran dan Pendidikan Islam Di Indonesia" Dalam Ulumul Quran Volume III No 4 Th 1992

Esposito John L, Islam the Straigh Path, terj Arif Maftuhin, (Bandung: Mizan, 2004)

Hasubullah,dkk, Sejarah Pendidikan Islam, (Jakarta: Bumi Aksara,1998 )

Makdisi Geroge, the Rise Of Colleges: Institution of Learning In Islam And The West, (Edinburg: Edinburg University Press, 1981)

Maksum, Madrasah:Sejarah dan Perkembangannya, (Jakarta:Logos,1999)

Munir Al-Dien Ahmad, Muslim Education And The Scholars Social Status, (Zurich, Verlag Der Islam, 1968)

Nakostem Mehdi, History Of Islamic Origins of Western, ( Colorado: University of Colorado Press, Boulder,1964)

Stanton Charles Michael, Pendidikan Tinggi Dalam Islam, ( Jakarta:Logos,1994)

Syalabi Ahmad, Sejarah Pendidikan Islam, (Jakarta:Bulan Bintang,1973) 
M. Mikihlis Fahrudd in-kuttab: Madrasah pada masa awal (Umayyah)

al-Tibawi, Arabic And Islamic Themes: Historical Educational and Literary Studies,(London And Luzac Company,1976)

,Islamic Education, Its Traditions and Modernization int the Arab Yunus

Mahmud, Sejarah Pendidikan Islam (Jakarta: Bumi Aksara, 1988 )

Zuhairi Dkk, Sejarah Pendidikan Islam, (Jakarta: Bumi Aksara,1991)

221 Madrasah, Vol.II No.2 Januari - juni 2010 